\title{
Joint monitoring of livestock stocking rates and rangeland vegetation of Hombori district in Mali during the 2010-2011 dry season
}

\author{
Mamadou Oumar DIAWARA ${ }^{1 *}$, Pierre HIERNAUX ${ }^{2}$, Eric MOUGIN ${ }^{3}$, Sory SISSOKO ${ }^{1}$, \\ Laurent KERGOAT ${ }^{3}$, Hawa Salif DIAKITE ${ }^{4}$, Abdoulaye DIALLO ${ }^{1}$ and \\ Nogmana SOUMAGUEL ${ }^{5}$
}
${ }^{1}$ Département de Biologie, Faculté des Sciences et Techniques (FST), Université des Sciences, des Techniques et des Technologies de Bamako (USTTB), Colline de Badalabougou, B.P. 3206 Bamako, Mali.
${ }^{2}$ Hiernaux, Pierre, Pastoc, 30 chemin de Jouanal, 82160 Caylus, France.
${ }^{3}$ Géosciences Environnement Toulouse (GET), Observatoire Midi-Pyrénées, Université de Toulouse, CNRS, IRD, 14 avenue Edouard Belin, 31400 Toulouse Cedex - France.
${ }^{4}$ Institut d'Economie Rurale (IER), Centre Régional de Recherche Agronomique de Sotuba (CRRA),
Laboratoire Sol - Eau - Plante, Unité Système d'Information Géographique et Télédétection, B.P. 262 Bamako, Mali.
${ }^{5}$ Centre IRD de Bamako, Quartier Hippodrome, BP. 2528 Bamako, Mali.
${ }^{*}$ Corresponding author; E-mail: diaprod@hotmail.com

\begin{abstract}
Sahel rangelands degradation is prone to many controversies. In Sahel, rangeland forage resources availability is characterized by large spatial heterogeneity and wide seasonal and interannual variations. Pastoral livestock systems adapt to these patchy and variation resources by herd mobility and some supplement feeding that only partially overcome seasonal forage shortages in dry years. This study aimed at analyzing the relationship between livestock stocking rates and forage availabilities during the 8-9 month dry season at the scale of the Hombori district. Stocking rates were estimated by monthly count of livestock by species, sex and age classes at the main pastoral water points. Herbaceous forage over the district was assessed at the onset of the dry season over using NDVI-MODIS remote sensing calibrated with in situ measurements. In addition, forage availabilities were monitored monthly in the service area of three selected water points as a function of distance from the water point up to $12 \mathrm{~km}$. The results indicated that despite the large numbers of livestock and the weak mobility of the resident herds, the overall stocking rate in the Hombori district remains low, as it entails an average grazing exploitation rate of only $9.4 \%$ of the fodder resource during the dry season. The grazing exploitation rate invalidates the statement of widespread 'overgrazing' of forage resources by livestock in the Sahel often advanced in rangeland ecology and management projects.
\end{abstract}

(C) 2020 International Formulae Group. All rights reserved.

Keywords: Rangelands, stocking rate, dry season, degradation rate, overgrazing, Sahel.

\section{INTRODUCTION}

The Sahel region located in tropical Africa between the latitudes $12^{\circ} \mathrm{N}$ and $20^{\circ} \mathrm{N}$, is characterized by a dry monsoonal climate with rainfall ranging from $100 \mathrm{~mm}$ in the north to $600 \mathrm{~mm}$ in the south (Nicholson, 2013). Rainfall are highly variable between years and the rainfall brought by convective events 
during the wet season are very patchy (Frappart et al., 2009).

Livestock numbers in this region are not exactly known because of the poor reliability and infrequent censuses. The livestock losses during the drought periods in the six Sahelian countries of West Africa (Mali, Senegal, Chad, Burkina Faso, Niger and Mauritania) were estimated between $25 \%$ and $50 \%$ of the livestock numbers prior to the drought depending on the country (Toulmin, 1985). However, a succession of wet years interspersed with very dry years that prevail since the mid-90s led to the rebuilding of livestock populations (Ickowicz et al., 2012). Despite small ruminant higher mortality, their number increased at a greater rate than cattle because of the diversity of their diet selection (Assouma et al., 2018) and their shorter reproductive cycle with lower age at first lambing/kidding and shorter duration between successive lambing/kidding. Food and Agriculture Organization of United Nations (2007) estimated the average annual increase of $4.1 \%$ for sheep and $5.9 \%$ for goats compared with $3 \%$ for cattle in West Africa based on national censuses.

The increase in livestock number combined with the reduction in rangeland area due to the expansion of cultivated fields in southern Sahel increased grazing pressure is often blamed of local environment degradation (Lhoste, 2007). Moreover, pastoralism is believed to lead desertification and the progression of the Sahara Desert to the south (Weber and Horst, 2011). The degradation diagnostic put forward overgrazing with seasonal stocking rates over the carrying capacity of the rangelands (McLeod, 1997). The carrying capacity concept also implies well defined animal production objectives which is a challenge in rangelands managed communally with mixes of livestock species and breeds. Moreover, herd seasonal mobility and communal management of rangeland resources in Sahel raise controversies as to the validity of the carrying capacity concept in a non-equilibrium ecosystem (Krätli et al., 2015).
The objective of this study were to analyze the relationship between stocking rates and forage availabilities during the dry season at the scale of the Hombori district. The stocking rates are derived from these numbers, and their impact on the seasonal dynamics of the herbaceous mass is calculated as a function of the distance from the main water points and verified along seven radial axis.

\section{MATERIALS AND METHODS Study site}

The study was carried out in the framework of an ecosystem research by the African Multidisciplinary Monsoon Analysis (AMMA) international research project and the Cycle Atmosphérique et Cycle Hydrologique (CATCH) observatory. The AMMA-CATCH observation site is the bioclimatic transect (1$2^{\circ}$ West $x$ 14.5-17.5 North) that stretches from the Niger River loop southward down to the border with Burkina Faso (Mougin et al., 2009). The field observations for this particular study focused on the district of Hombori at center of that bioclimatic transect and were carried out between March 2010 and June 2011.

The Hombori district extends over 2923 $\mathrm{km}^{2}$ and was populated by 13894 inhabitants in 2009. Its climate is tropical dry driven by the West African Monsoon. Rains begin in July and end in September with a peak in August. The annual mean rainfall from 1922 to 2017 is $370 \mathrm{~mm}$ at Hombori (Galle et al., 2018). The dry season lasts nine months and is divided into two sub-seasons: a cool dry season from November to February, and a hot dry season from March to June. The month of October with a few possible rains and hot temperatures is considered transitional.

The main economic activity of the population is pastoral husbandry. Livestock production relies on communally managed native pastures which production is highly dependent on the rainfall amounts and patterns. The high variability of the rainfall distribution renders rain-fed crops very risky. 


\section{Rangeland vegetation monitoring forage availability at the onset of the dry season (NDVI-MODIS)}

The herbaceous yield in late growing season was measured in the four vegetation sites listed above. The measure method was destructive with cutting at ground level in stratified random $1 \times 1 \mathrm{~m}$ samples along transects of $1000 \mathrm{~m}$ long. The stratification was done in two steps facieses may be recognized when the species composition markedly distinguishes between topographic, geomorphological or land use components. Each vegetation facies are stratified according to apparent bulk of herbaceous layer in four strata: $\mathrm{O}=$ bare soil, $\mathrm{L}=$ low, $\mathrm{M}=$ median and $\mathrm{H}=$ high bulk densities (Hiernaux et al., 2009). The stratification is recorded each meter along one or two $1000 \mathrm{~m}$ long linear transect at each site. Three (strata $\mathrm{L}$ and $\mathrm{H}$ ) or six (strata $\mathrm{M}$ ) random samples $1 \mathrm{x} 1 \mathrm{~m}$, of the herbaceous layer are selected along the transects to assess cover, height, plant density, species composition and to measure herbaceous mass by mowing at ground level, drying and weighing. In the dry season standing straws and litter are harvested separately. The site variables were calculated by weighting the strata means by the relative frequency of the strata along the $1000 \mathrm{~m}$ transect (Hiernaux et al., 2009).

The herbaceous fodder availability at the end of the growing season, in the late September, was assessed over the entire district of Hombori and surroundings by the mean of a linear regression:

\section{HDMM = 9979.4 $\times$ mNDVI $-738.09 \quad r=$ 0.75}

established between the herbaceous dry matter mass (HDMM, $\mathrm{kg} \mathrm{ha}^{-1}$ ) measured in 12 vegetation sites and the wet season (10 June 30 September 2010) mean of the Normalized Difference Vegetation Index (mNDVI) (L3 Global $250 \mathrm{~m}$ ) in 16 days composites (maximum NDVI within the 16 days) provided by the MODIS-Terra satellite (downloaded from http://daac.oml.gov/modiswebservice).

\section{Long term monitoring of Gourma rangeland sites}

The monitoring of rangeland resources was initiated in 1984 on 30 vegetation sites sampled by the International Livestock Center for Africa (ILCA) and research teams of the Institut d'Economie Rurale (IER). The goal was to assess the impact of the drought that occurred on the rangelands and pastoral production systems in 1983-84 years and the observations were continued till 1994. The monitoring was resumed in 2000 under the African Multidisciplinary Monsoon Analysis (AMMA) - Cycle Atmosphérique and Cycle Hydrologique (CATCH) observing system (Mougin et al., 2009).

The 30 monitoring sites arranged along bioclimatic and edaphic gradients were done the regular measurements of herbaceous and wood plant cover, standing mass and species composition. Meteorological data such as rainfall, temperature, wind speed and direction of the wind, soil moisture were recorded. Ten of 30 monitoring sites are located in the Hombori district and surroundings. Four of these ten vegetation sites (Agoufou, Timbadior, Hombori-Hondo and Tara), located at various distances from permanent water points were selected to conduct a monitoring of the herbaceous vegetation and livestock attendance during the 2010-2011 dry season (Figure 1).

The four selected sites were subjected to disparate seasonal grazing pressure allowing the assessment of the impact of livestock on the short-term dynamics of the herbaceous layer during the dry season. This assessment was conducted along a radial axis of 3 to $14 \mathrm{~km}$ long with beacons every $500 \mathrm{~m}$, radial from the water points: the Agoufou permanent pond, the well of Bilantao, temporary ponds relayed by two wells in Kelma.

\section{Monitoring of the Forage availability from October to June}

The forage availability from October to June associate observations and destructive measures performed in the four selected sites 
under similar stratified sampling as for the measure of September, to systematic visual estimates performed along 7 axes each radiating from three selected water points. The field visual estimates were made for each 100 $\mathrm{m}$ segment along each radial transects, and they include: the extent (\%) of bare soil patches, the proportion of standing straw (\% extend of classes) within the herbaceous mass also composed of litter. To try and reduce estimate errors, the assessments were preceded by autocalibration tests. These tests consist of the visual estimation of the herbaceous mass and the proportion of standing straw in a random sample of $201 \times 1 \mathrm{~m}$ quadrats along the radial axis. Standing straws and litter are then harvested and weighed and compared to the estimations. These auto-calibration tests were run several times during the dry seasons. From the herbaceous mass measures on the 4 vegetation sites and estimates on the 7 radial axis monthly loss rates of herbaceous mass were calculated as the ratio of the difference in mass between two consecutive observations $\left(D_{i}, D_{i+1}\right)$ on the mass at the first observation reduced to a period of 30 days following the equation:

\section{$\left(\right.$ HDMM $_{\text {D }}-$ HDMM $\left._{\text {D1 }}\right) /\left(\right.$ HDMM $\left._{\text {D }}\right) \times(30 /$ $\mathrm{D}_{1}$ - D)}

$\operatorname{HDMM}\left(\mathrm{D}_{1}\right)$ denotes the herbaceous dry mass measured at the date $\mathrm{D}_{1}$ and HDMM (D), the herbaceous dry mass measured at the time D.

The dynamics of the herbaceous mass during the dry season was also assessed by remote sensing using the Soil Tillage Index (STI), provided by MODIS (MCD43A4, collection 5) every 8 days at a spatial resolution of $500 \mathrm{~m}$. The STI index is the ratio between bands b6 (1628 - $1652 \mathrm{~nm})$ and b7 (2105 - 2155 $\mathrm{nm})$. It has been used to estimate dry season forage mass (Jacques et al., 2014; Kergoat et al., 2015). To estimate the mass of straws and litter in the study area during the 2010-2011 dry season we used the linear regression established by Jacques et al. (2014) between the STI index and the dry season (2004-2011) herbaceous mass (HDMM) of 20 of the AMMA-CATCH long term vegetation sites in the Gourma region including the 4 sites retained in this study:

$$
\text { HDMM = } 3371 \times(\text { STI - 1.06) } \quad r=0.75
$$

STI derived mass estimates were extracted in the four selected sites and along the seven radial transects and compared with field estimates. The STI derived herbaceous mass estimates were then used to assess the forage seasonal dynamics over the whole study area and particularly within the service areas of the 55 seasonally monitored water points. Monthly loss rates of herbaceous mass were calculated from the STI derived estimates as for field measures and estimates.

\section{Monitored water points}

Most of the water points in the Hombori district are used to water livestock. They capture the functional diversity of water sources in the Sahel with temporary and permanent ponds, deep and shallow wells, boreholes and cisterns. Wells and boreholes have lower capacities to provide water to livestock because of the chore or the cost required to draw the water out. Typically wells and boreholes are used from March to June depending on years and forage availability at their vicinity. The cisterns are exploited in the middle dry season with limited access due to their small capacity and the competition of other domestic uses. In a few sites, shallow wells relay temporary ponds and give opportunities to water livestock from March to July of wet years and from February to May dry years.

\section{Herd monitoring}

Livestock numbers per herd were systematically recorded over 24 hours, once every month at the water points on the same day than the visual estimates of herbaceous mass were performed along the radial transects. Indeed, during the dry season livestock are watered every day or every two days (Diawara, 2015) at a limited number of permanent water points. For each herd, the timing and the composition of the herd are systematically recorded by species, sex and three age classes: adult, weaned young and unweaned young. Also, a survey is done with the herder/shepherd 
on watering frequency and timing, and the corral and grazing areas locations.

To assess the overall stocking rates, the livestock numbers by species and sex-age classes were converted into Tropical Livestock Unit, TLU (Table 1) based on average live weight of each category from existing literature (Wilson, 2003). The daily livestock fodder intake is assessed based on the number and metabolic weight of each species and sex-age and the mean dry matter intake per unit metabolic weight $99 \mathrm{~g} \mathrm{~kg} \mathrm{LW}^{0.75}$ (Table 2). Livestock numbers recorded monthly at each water point and the aggregated fodder intake were assigned to circular service areas centered on the water point to assess the stocking rate (TLU $\mathrm{km}^{-2}$ ) and the grazing pressure by the ratio of aggregated livestock intake on the fodder mass available at the onset of the month.

\section{Barycentric model of the spatial distribution of grazing livestock}

The service area of a water point is modeled as a circle centered on the water point which radius evolves from $6 \mathrm{~km}$ at the onset of the dry season, in October, up to $12 \mathrm{~km}$ at most.
Indeed, the service area increases by onekilometer radius whenever the forage resources within the grazed service area has decreased by at least $20 \%$ during the previous month. The radius may increase up to a maximum of $12 \mathrm{~km}$ which is considered the maximum distance a herd can travel to be watered daily (Schlecht et al., 2006) which, according to the survey, applies to most of the herds monitored (96\%).

In a second step, all the monitored water points were arranged into 20 clusters, based on the distance between water point and the complementary use by livestock. All remote water points within $12 \mathrm{~km}$ were grouped in a cluster. Within clusters stocking rates were added. The grazing intensity during the dry season was estimated by the ratio of the aggregated forage intake to the forage mass at the onset of the dry season.

The barycentric model was developed in $\mathrm{R}$ (https://cran.r-project.org) statistical processing and programming software. The model estimates and shares out stocking rates at different spatial scales. It was based on the forage use availability in a previously userdefined area.

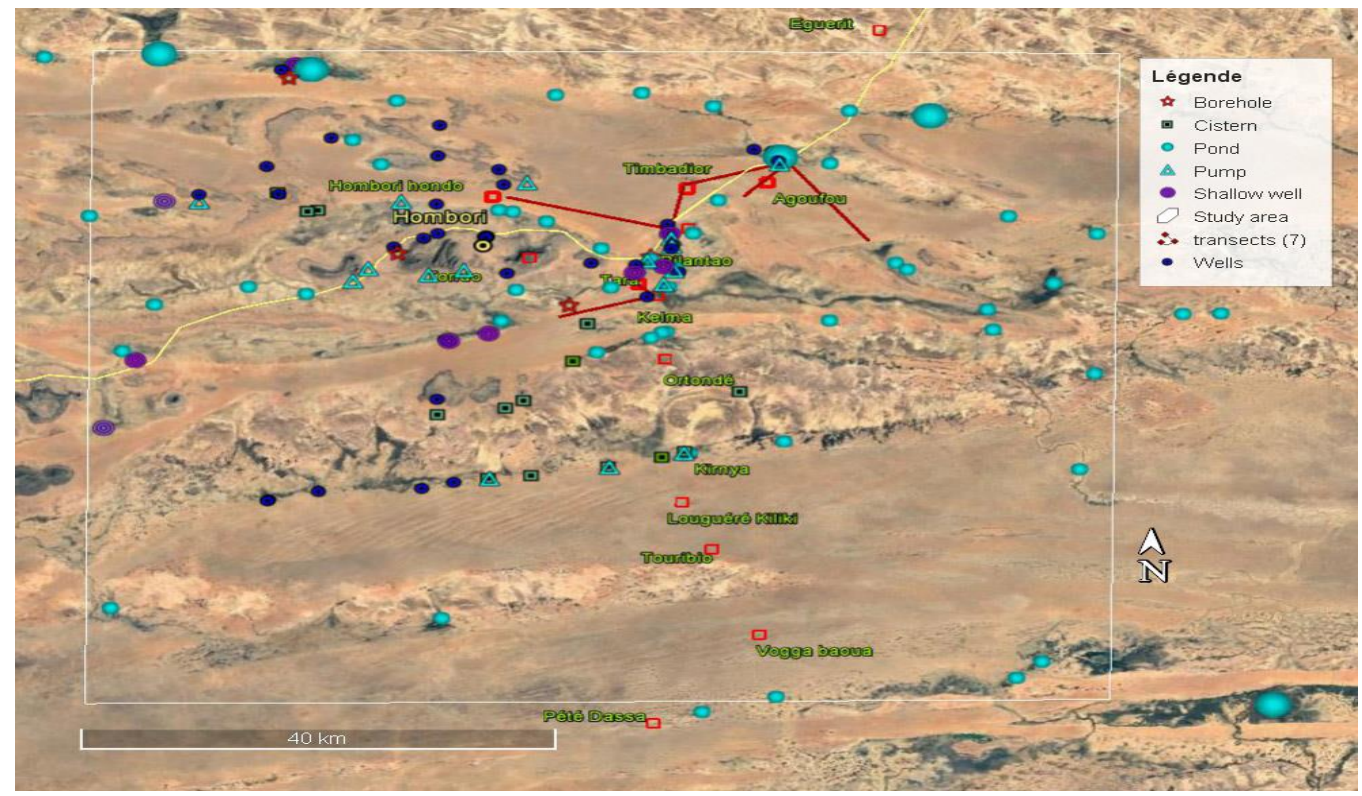

Figure 1: The observation setting in the district of Hombori (Eastern Mali): the monitored water points, the 4 rangeland sites (on sandy soils) and the 7 radial axis from three selected water points (Agoufou pond, Bilantao well and Kelma ponds and wells). 
Table 1: Conversion coefficients of livestock numbers by species and age classes in live weight estimates expressed in Tropical Livestock Unit, TLU.

\begin{tabular}{cccc}
\hline Species & \multicolumn{2}{c}{ Tropical Livestock Unit equivalent $(250$ kg Live weight) } \\
& Adults & Young weaned & Young unweaned \\
\hline Cattle & 0.8 & 0.4 & 0.2 \\
Sheep & 0.12 & 0.06 & 0.03 \\
Goat & 0.08 & 0.04 & 0.02 \\
Donkey & 0.6 & 0.3 & 0.15 \\
Camel & 1.2 & 0.6 & 0.3 \\
Horse & 1 & 0.5 & 0.2 \\
\hline
\end{tabular}

Table 2: Norms of daily fodder intake during the dry season (in kg forage dry matter) by livestock species and age classes based on the overall norm of $99 \mathrm{~g}$ per $\mathrm{kg}$ of metabolic weight $\left(\mathrm{LW}^{0.75}\right)$ and on the mean live weight of each livestock category (Table 1).

\begin{tabular}{cccc}
\hline Species & \multicolumn{3}{c}{$\begin{array}{c}\text { Daily fodder intake (kg DM d } \\
\text {-1 }\end{array}$} \\
& Adults & Young weaned & Young unweaned \\
\hline Cattle & 5.3 & 3.1 & 1.6 \\
Sheep & 1.1 & 0.7 & 0.3 \\
Goat & 0.9 & 0.6 & 0.3 \\
Donkey & 4.2 & 2.5 & 1.3 \\
Camel & 7.1 & 4.2 & 2.1 \\
Horse & 6.2 & 3.7 & 1.9 \\
\hline
\end{tabular}

\section{RESULTS}

Fodder resources distribution at the end of the 2010 growing season

The herbaceous mass measured in September 2010 in long-term monitoring sites located in the Hombori district range between $375 \pm 172 \mathrm{~kg} \mathrm{DM} \mathrm{ha}^{-1}$ on shallow soils; $2580 \pm$ $212 \mathrm{~kg} \mathrm{DM} \mathrm{ha}^{-1}$ on low land clayed soils. On these sandy soils the higher yields were measured in the site of Agoufou (2433 \pm 179 kg DM ha-1) and Tara $\left(2694 \pm 244 \mathrm{~kg} \mathrm{DM} \mathrm{ha}^{-}\right.$ $\left.{ }^{1}\right)$ despite their proximity to villages and permanent water points. In Timbadior and Hombori-Hondo rangeland sites, the herbaceous production was lower respectively in $1173 \pm 69$ and $1274 \pm 94 \mathrm{~kg} \mathrm{DM} \mathrm{ha}^{-1}$. The average herbage mass over the whole study area estimated by regression of mean NDVI value over the growing season was $1844.9 \pm$ $747.9 \mathrm{~kg} \mathrm{DM} \mathrm{ha}{ }^{-1}$. This production was greater than the average production estimated for the last ten years (Dardel et al., 2014). However, the spatial heterogeneity is high in relation with soil texture and redistribution of surface water by run-off as indicated by the map of the fodder resources of the district of Hombori and surroundings at the end of the 2010 growing season (Figure 2).

The average herbaceous production estimated by the NDVI metrics in clay plains 
equals $2664.3 \pm 519.1 \mathrm{~kg} \mathrm{DM} \mathrm{ha}^{-1}$ and it equals $2122.1 \pm 290.2 \mathrm{~kg} \mathrm{DM} \mathrm{ha}^{-1}$ in the deep sandy soils $(65 \%$ of the area). Both means are close to the mean of the herbaceous mass measured on the sample sites in clay and sandy soil, while the mean production estimated by NDVI on the loamy soil, hard pan and sandstone outcrop sites is estimated at $925.6 \pm 328.9 \mathrm{~kg} \mathrm{DM} \mathrm{ha}^{-1}$ superior to the mean mass measured on the $n$ sites monitored on shallow soils within the district of Hombori.

\section{Remote sensing estimates of the herbaceous decay during the dry season}

The herbaceous mass estimated from the Simple Tillage Index (STI) values were extracted along the radial axis and the values plotted against the visual estimations made along the 7 radial axis during the dry season the 10th of November, 11 of February, 11 of April and 11 of June (Figure 3). The correlation indicates a good fit $(\mathrm{r}=0.87 ; \mathrm{n}=80)$ between the two estimations. The standing straw and litter mass dynamics during the dry season were established for 20 vegetation sites of the Gourma region in Mali using STI estimations (Jacques et al., 2014). For the 4 vegetation sites close to the three selected water points and transects, Jacques et al. (2014) obtained $\mathrm{r}=$ 0.74 over 232 measures and 8 years period (2004-2011).

\section{Straws and litter mass dynamics during the dry season along the radial axis}

The monthly disappearance of herbaceous mass as derived from the STI along the 7 radial axes indicate strong losses along the dry season (Figure 4a). The rates of losses were not constant throughout the season (Figure $4 \mathrm{~b}$ ). They were high at the dry season onset, $31.7 \%$ on average between the late rains and the end of November. Loss rates stabilize from February on, with smaller spatial heterogeneity, and increase again at the end of the dry season with rapid decomposition triggered by the first rains. The rate of losses also differs between axis depending on the intensity of the grazing pressure related to the number of livestock using each water point and the availability of forage resources in their service areas. The exceptionally high rate of loss observed in February along the Hombori Hondo axis from the Bilantao well is due to an accidental fire that burned the straws and litter over half the transect length.

\section{Spatial distribution of the livestock stocking rates}

The stocking rates were mapped monthly over the Hombori district and surroundings using the barycentric model outputs (Figure 5). These maps revealed the strong spatial heterogeneity of livestock distribution concerning the distance to accessible water points and their capacity to provide water. For permanent and temporary ponds, the monthly means vary by $61 \%$ from November 2010 and June 2011 around shallow wells, by $36 \%$ around cisterns, by $35 \%$ around wells and only by $13 \%$ around boreholes. Despite water availability spans over the whole dry season in wells and boreholes they are of secondary importance to water livestock because of the work and cost of water lifting. The livestock watered from wells and boreholes were few and in relatively stable number over time. Livestock numbers watered from cisterns were also low and stable, because of the small storage capacity of the cisterns and their private management. On the contrary, livestock numbers watered from permanent ponds and shallow wells that relay temporary ponds when they dry up were large and vary greatly during the dry season.

\section{Comparing the barycentric model predictions to the transect field observations}

The trends of herbaceous mass obtained by interpolation from the herbaceous mass losses calculated in the service area of the water points were compared to the herbaceous loss rates estimated on the field through visual estimates of the herbaceous masses along the 7 radial axis (Figure 6). The comparison bears on the average loss rates of the herbaceous mass every kilometer along each axis. Despite the limitations of the interpolation method only based on distance from the water point, which 
tends to overestimate stocking rates where water point service areas overlap each other, the loss rates calculated with the barycentric model fit the loss rates observed on the field. Close to permanent ponds, seasonal loss rates of herbaceous mass exceed $82.4 \%$ of the mass at the onset of the dry season, when the same rates are $61.5 \%$ at $10 \mathrm{~km}$ away from the pond.

\section{Grazing efficiency}

The exploitation rate of forage has been calculated for the service areas of the 20 water point clusters (Figure 7a) the ratio of cumulated grazing uptake by the variable livestock numbers (Figure 7b) during the dry season over total herbaceous mass at the onset of the dry season. The rates of grazing exploitation over the Hombori district and surroundings were overall low with large variability between water point clusters, being $9.4 \%$ on average with a coefficient of variation of $96.9 \%$. The drying up of most ponds early in the dry season severely limits the rangeland area accessible for grazing during the second half of the dry season and leads to a concentration of livestock around the few permanent ponds. Around these permanent ponds (Agoufou and Dimamou) and to a lesser extent close to the deep and shallow wells (such as Bilantao), the forage utilization rate reaches the maximum limit which equals $1 / 3$ of the herbaceous mass at the onset of the dry season.

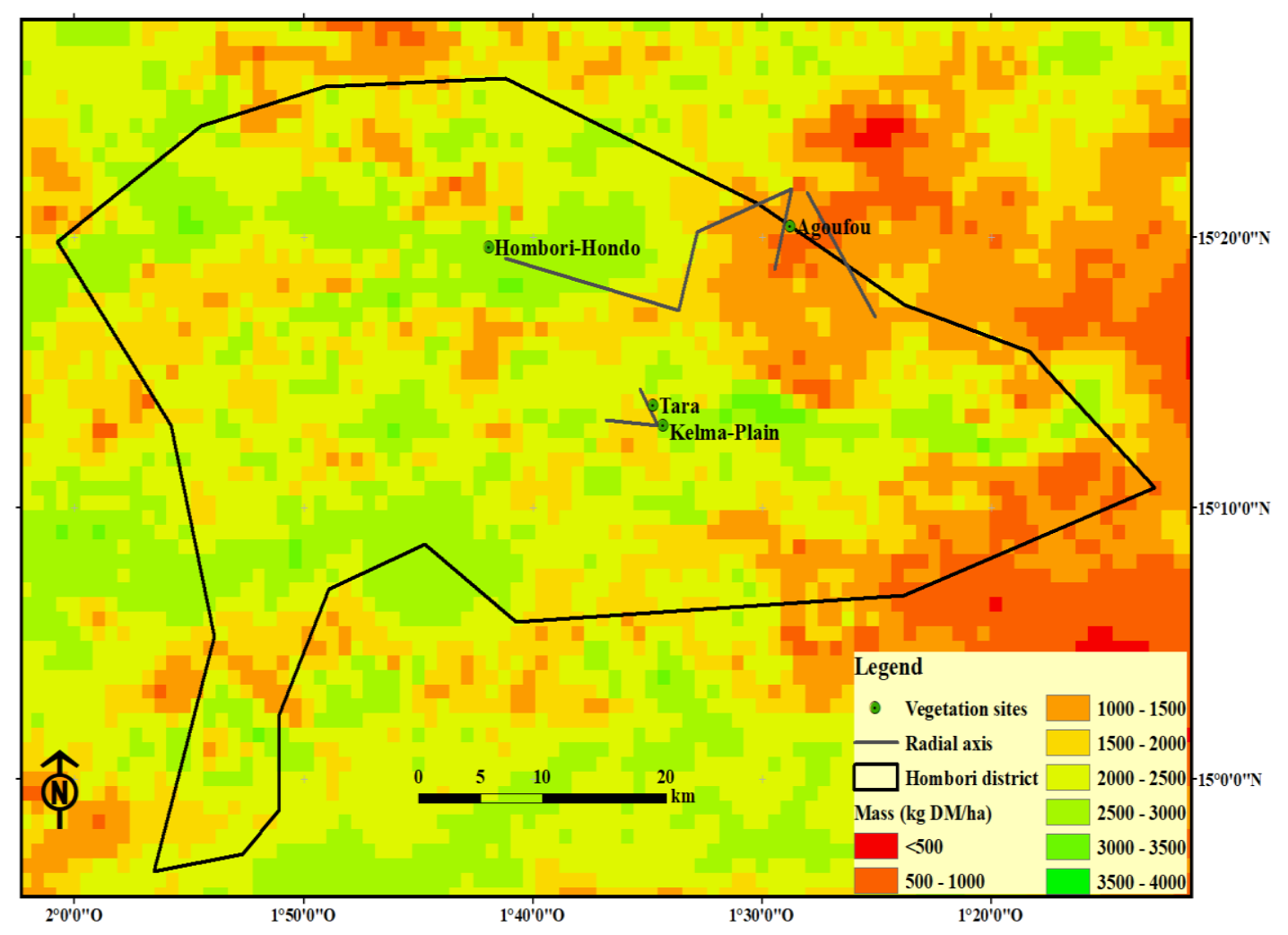

Figure 2: Spatial distribution of fodder availability at the end of the 2010 growing season. 


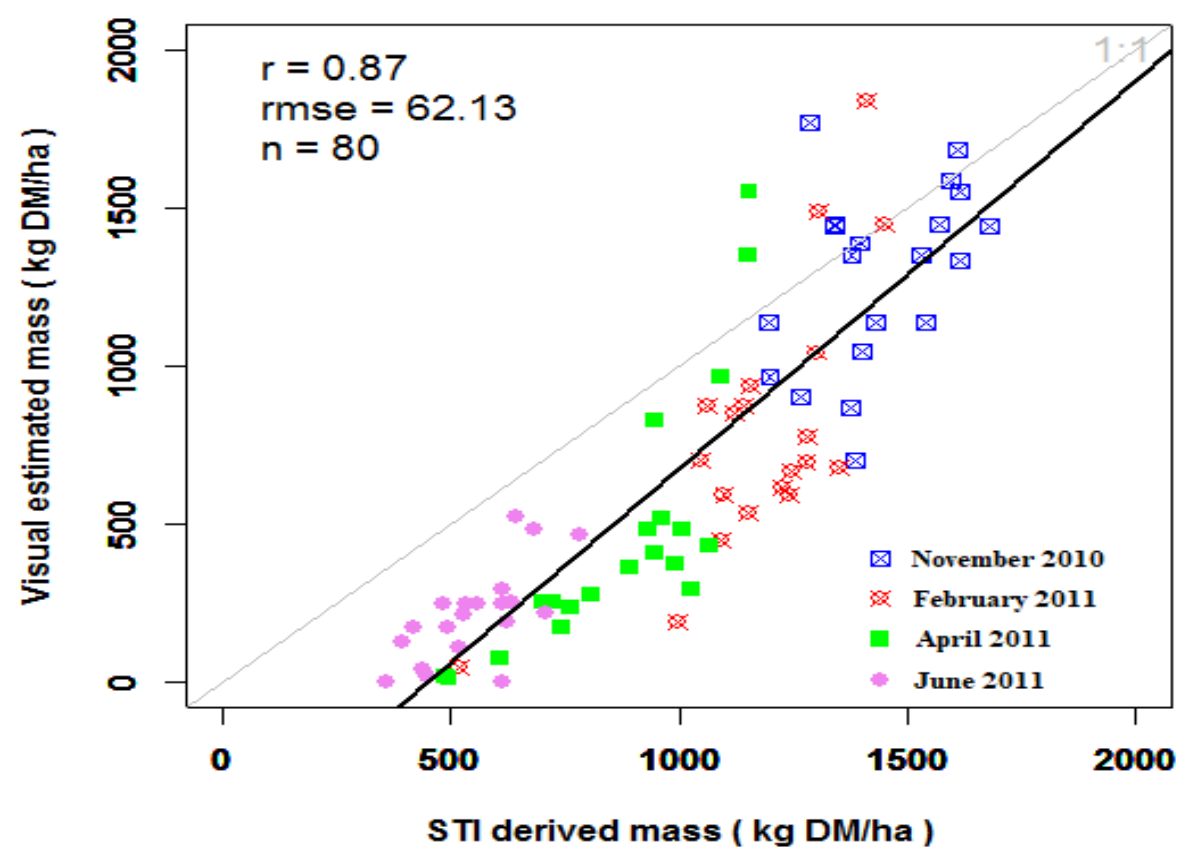

Figure 3: Comparison between STI derived herbaceous mass and visual estimated mass along Agoufou-Bongho radial axis $\left(15.36^{\circ} \mathrm{N},-1.46^{\circ} \mathrm{W} ; 15.28^{\circ} \mathrm{N},-1.41^{\circ} \mathrm{W}\right)$ during the $2010-2011 \mathrm{dry}$ season.

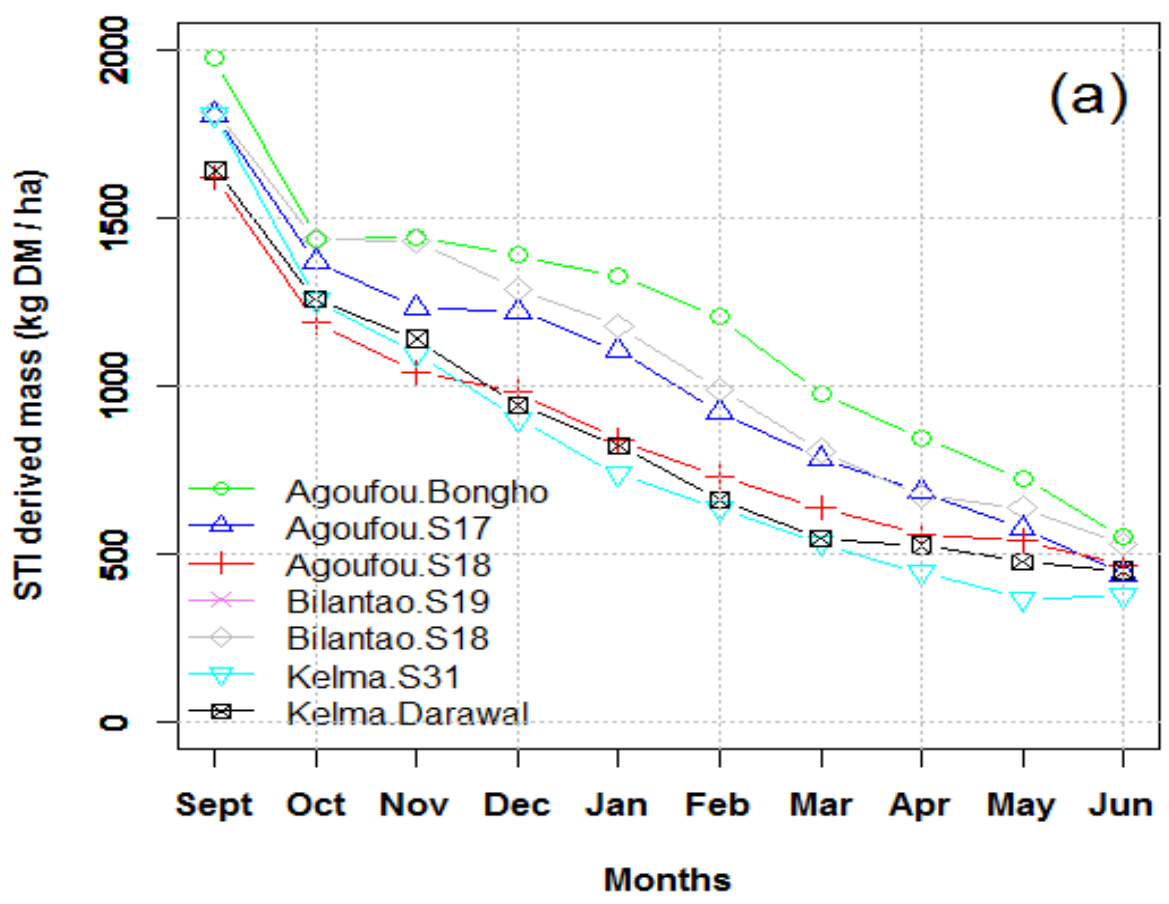




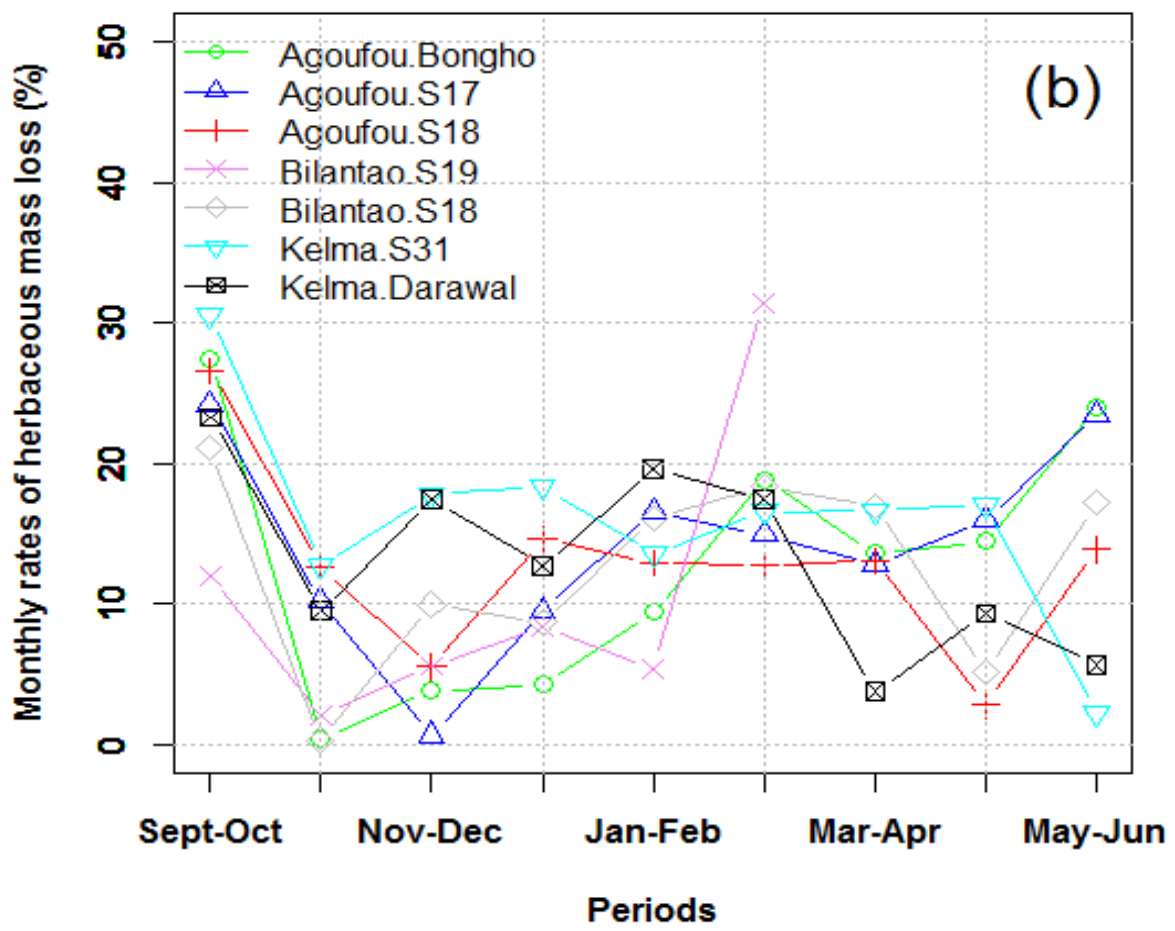

Figure 4: The dynamics of dry season herbaceous mass along 7 radial axis from Agoufou, Bilantao and Kelma water points from satellite estimates (a) and monthly rate of herbaceous mass (in \% of the mass at the end of the previous month) loss assessed this radial axis (b).
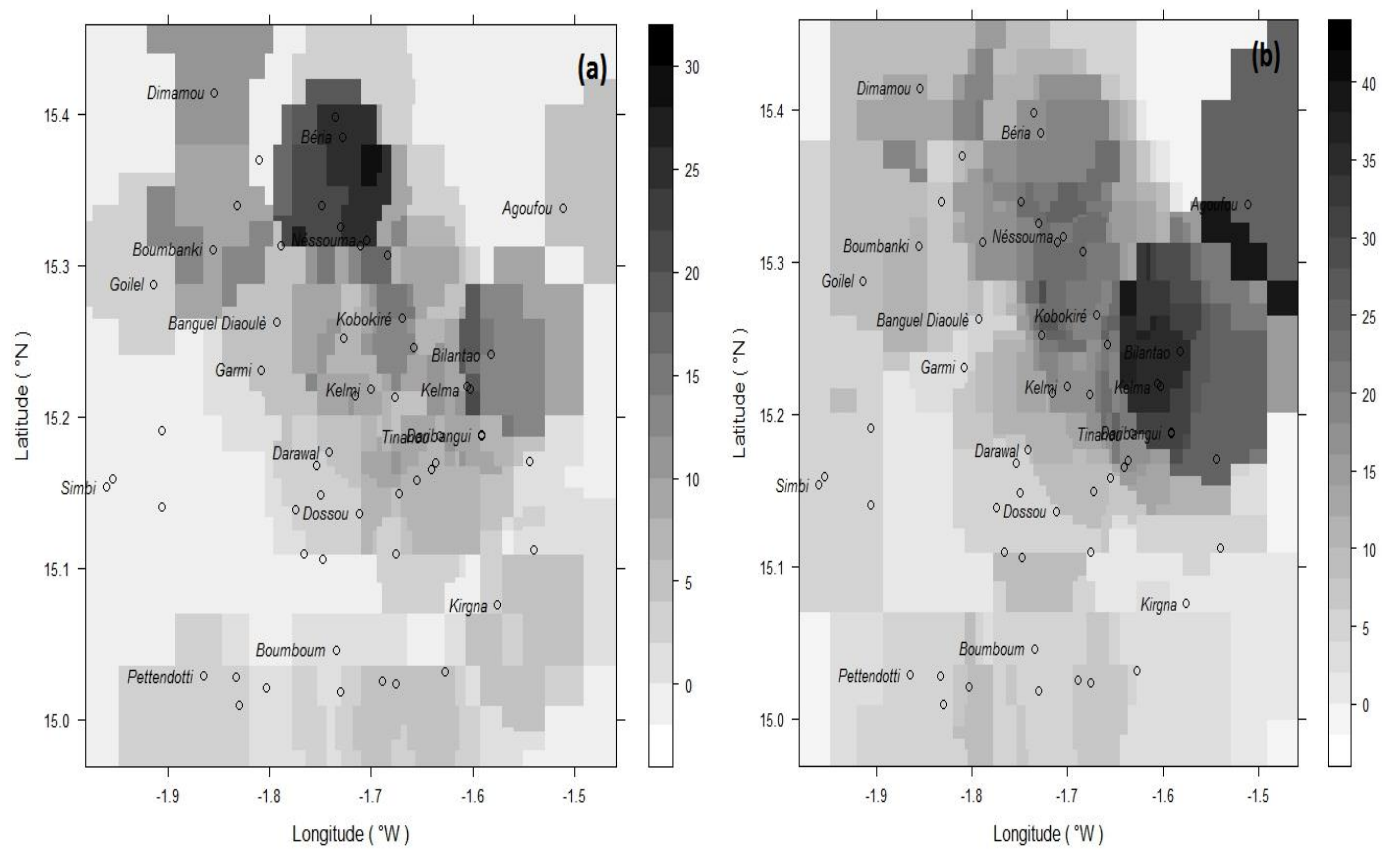


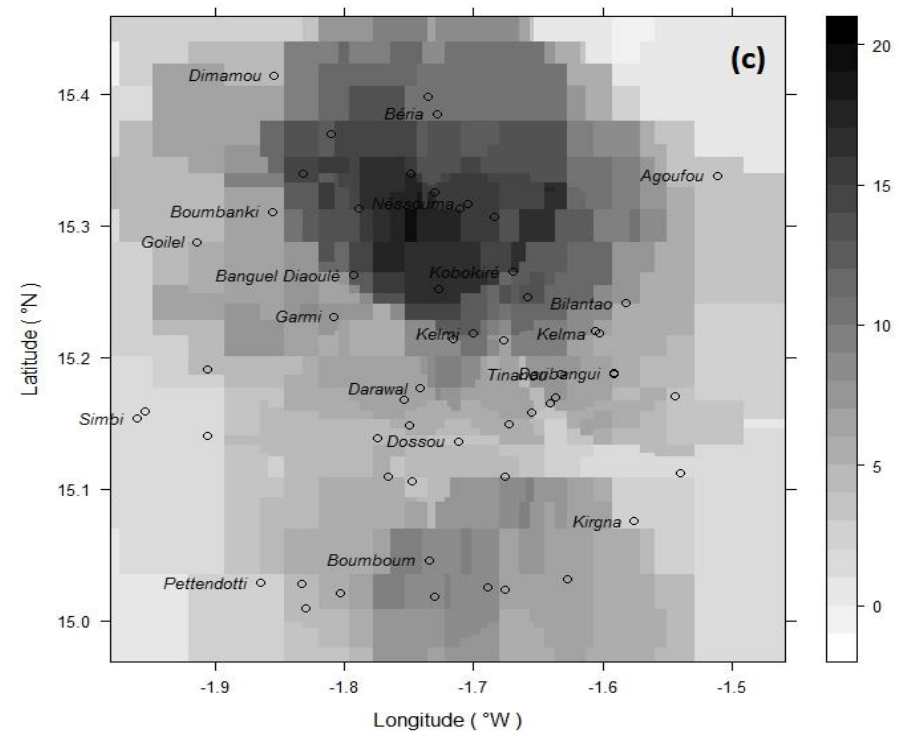

Figure 5: Spatial distribution of livestock stocking rates $\left(\mathrm{TLU} \mathrm{km}{ }^{-2}\right)$ over the district of Hombori and surroundings in November 2010 (a), March 2011 (b) and June 2011 (c).

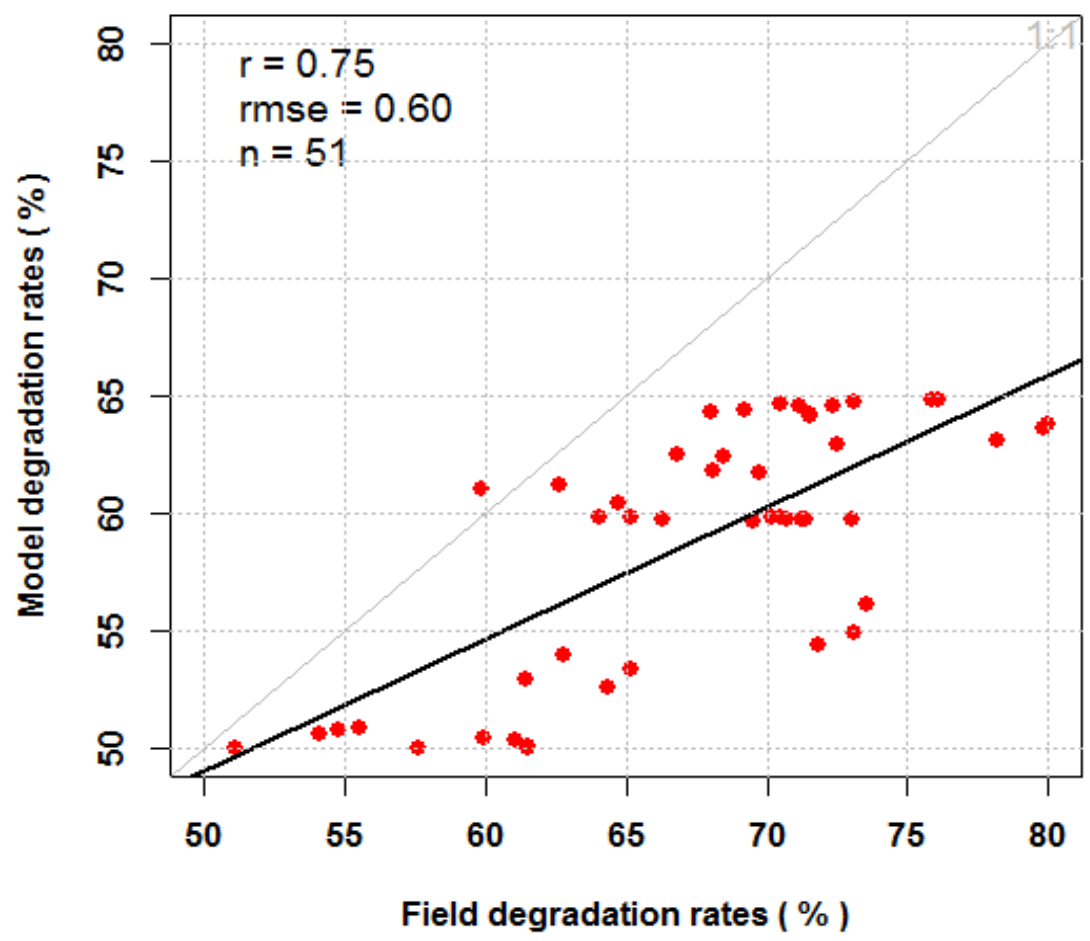

Figure 6: Comparison between the barycentric grazing model of herbaceous cumulated loss rates and cumulated loss rates estimated from visual estimates of herbaceous masses along 7 radial axis from the water points. 

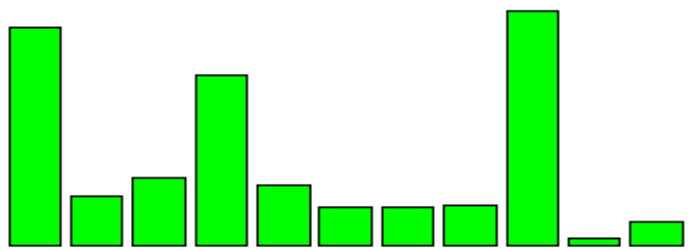

(a)

mean $=9.4$

std $=8.9$

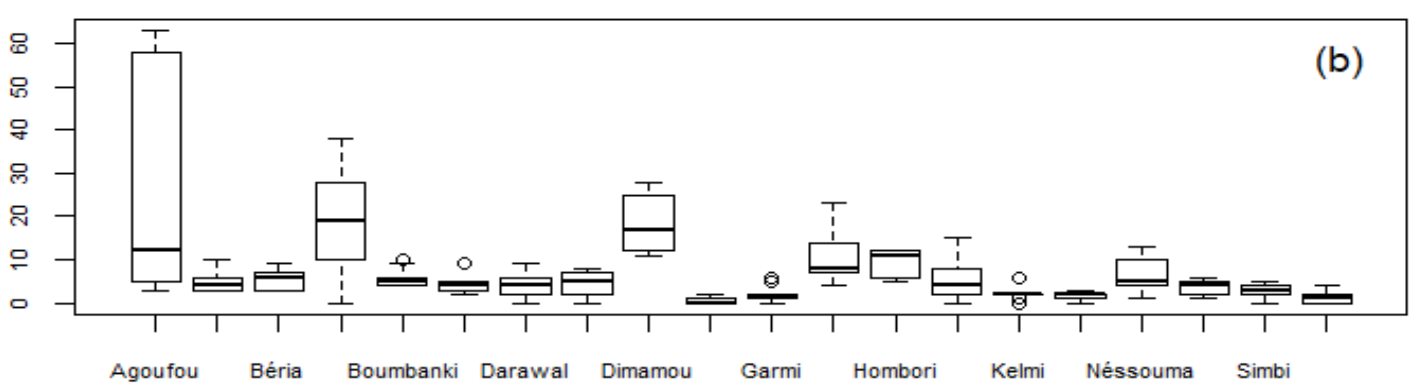

Water points clusters

Figure 7: The impact of the grazing intensity on the herbaceous mass losses during the dry season around pastoral water points: (a) rate of pastoral exploitation of the herbaceous fodder assessed over the potential service area of the water points from October 2010 to June 2011; (b) median, lower and upper quartiles, minimum and maximum stocking rates assessed in the potential service area of each water point from October 2010 to June 2011.

\section{DISCUSSION}

\section{Straws and litter decay during the dry season}

The residual mass of straws by the end of the dry season in the four sites monitored only accounted for 9.8, 6.4 and $1.3 \%$ of herbaceous mass at the onset of the dry season in the Agoufou, Timbadior and Tara sites respectively located at $2.3,10.1$ and $1.6 \mathrm{~km}$ from the closer permanent water point. Indeed, in addition to forage intake, trampling and the time livestock rest and ruminate by the water point also contributes to the loss of standing straws and litter masses. In average livestock spend one and a half hours by wells and boreholes while they spend about three hours by permanent ponds. This rumination time depends on the livestock species, watering frequency, and the water point accessibility and capacity to provide water.

The high rate of disappearance of the straws at the vicinity of the water points following the transfer from standing straw to litter mass is often mentioned as a trait of Sahel pastoral overgrazing (Sanon et al., 2015). This high loss rate could be due to the high rate of organic decomposition with remnant soil moisture and still high atmospheric humidity (Delon et al., 2015), it could be favored by the massive dispersion of diaspores, especially that of grasses, and shade and rapid decomposition of the leaves of some of the herbaceous dicotyledons, including the legumes Zornia glochidiata and Alysicarpus ovalifolius, also Cassia ssp, Tribulus terrestris (Diawara et al., 2018). 


\section{Assessing stocking rate, fodder intake with the barycentric model}

The stocking rates calculated over the service areas were most likely a bit lower than the actual stocking rates in the district because all water points were not surveyed. The spatial distribution of the stocking rates was also to be taken cautiously because of the simplifications made in their assessment. For example, if the stocking rate is considered even within the circular service area whereas, it probably higher at the vicinity of the water point and decreases as one moves away from it. Despite these limitations, the study has identified the areas where livestock concentrated during the dry season, with potential risks of rangeland degradation and livestock losses.

The fodder intake estimates are crude, they don't account for the live weight difference between males and females, for weight losses of animals during the dry season, or for adaptative grazing selection by livestock (Fernandez-Rivera et al., 2005).

The trends of herbaceous mass obtained by interpolation from the herbaceous mass losses calculated in the service area of the water points were compared to the herbaceous loss rates estimated on the field through visual estimates of the herbaceous masses along the 7 radial axis. The comparison bears on the average loss rates of the herbaceous mass every kilometer along with each axis. Despite the limitations of the interpolation method only based on distance from the water point, which tends to overestimate stocking rates where water point service areas overlap each other, the loss rates calculated with the barycentric model fit the loss rates observed on the field. Close to permanent ponds, seasonal loss rates of herbaceous mass exceed $82.4 \%$ of the mass at the onset of the dry season, when the same rates are $61.5 \%$ at $10 \mathrm{~km}$ away from the pond. The loss rates of herbaceous masses during the dry season calculated based on the grazing pressure assessed by the barycentric model were plausible, close to the rates reported by Valenza and Diallo (1972) for Senegal rangelands between the last rains to March range from June. It seems however, that the barycentric model outputs slightly underestimate the loss rates in the vicinity of the water points.

\section{Rate of fodder use: are the rangelands under or over grazed?}

Comparing the aggregated fodder uptake with the rates of herbaceous losses reveals that a large fraction of the herbaceous mass losses during the dry season is not due to livestock intake but either to other herbivore consumption, including termite and other insects and rodents, physical break down accelerated by livestock trampling or fungal and microbial decomposition (Diawara et al., 2018). In all these cases this disappearing herbaceous mass, at least two thirds of the standing mass at the onset of the dry season, is locally recycled (Hiernaux et al., 2013).

The mean rate of fodder intake in the service areas of the 20 water point clusters indicates that despite the large numbers of livestock recorded at the water points and the weak mobility of the resident herds, the overall stocking rate in the Hombori district remains low, as it involved an average grazing exploitation rate of only $9.4 \%$ of the fodder resource. This rate invalidates the statement of widespread 'overgrazing' of forage resources by livestock in the northern Sahel (Zampaligré et al., 2019) often advanced in rangeland ecology and development and natural resource management projects, and already questioned in the 80's (Gilles and Jamtgaard, 1981). However, stocking rates and forage use rates varied widely between service areas of water point clusters. The forage use rates estimated in the service areas of the permanent ponds reach $33 \%$ which is close to the maximum rate possible considering the unavoidable effects of trampling, other herbivores and organic decomposition processes (Diawara et al., 2018).

The high grazing rates observed locally at the vicinity of permanent water points mitigate the diagnostic of overall underutilization of fodder resources based on the district average rate of $9.4 \%$; the use intensity is thus a matter of scale. The overall 
under-using rate observed in the district of Hombori and surroundings during the 20102011 dry season should also be put in perspective, as rainfall were particularly abundant and well distributed in 2010 in Hombori $(433 \mathrm{~mm})$ and surrounding districts (Dardel et al., 2014) contributing to limit the inflow of 'foreign' herds this year and therefore the stocking rates.

\section{Conclusion}

At the scale of the Hombori district, rangelands were not subject to grazing exceeding fodder availability. Hence this result disputes the concept of rangeland overgrazing often alleged in the Sahel. However, the herbaceous masses observed at the vicinity of a water point in the late dry season were often below $100 \mathrm{~kg} \mathrm{DM} \mathrm{ha}^{-1}$ of litter and therefore enhance the risk of soil deflation or top soil crusting due to trampling.

The barycentric model offers good prospects to assess the use of commonly managed rangelands during the dry season. One of the merits of the tool is to work at a range of scales from individual water points (livestock counts), to service areas for individual and clusters of water points and whole territories such as administrative districts. The model only applies to graze livestock in communally managed rangelands. Its application could rely easily on accessible satellite remote sensing estimates of rangeland fodder resources but requires laborious seasonal monitoring of livestock populations at the water points. Providing these precise and timely data on livestock numbers are recorded, the barycentric model could guide infrastructure management (water points, livestock corridors) and pastoral livestock development projects. It could technically support the implementation of policies targeting the reduction of livestock productivity losses though optimal use of the forage resource during the dry season.

\section{COMPETING INTERESTS}

The authors declare that they have no competing interests.

\section{AUTHORS' CONTRIBUTIONS}

All authors contributed to the field work data collection, MOD conceived, designed the monitoring, conducted some of the analyses, wrote the manuscript, $\mathrm{PH}$ conducted some of the analyses and, EM, SS and LK conducted some of the analyses too and provided editorial advices.

\section{ACKNOWLEDGMENTS}

This work was partially funded by the (French) National Research Agency as part of the ECliS (Livestock, Climate and Society) research project. The authors are indebted towards the researchers and technicians of the AMMA-CATCH Observatory Service in Mali. The authors are grateful to the fellow investigators who contributed to the surveys and the herders of the Hombori district for their availability and patience.

\section{REFERENCES}

Assouma MH, Lecomte P, Hiernaux P, Ickowicz A, Corniaux C, Decruyenaere V, Diarra AR, Vayssières J. 2018. How to better account for livestock diversity and fodder seasonality in assessing the fodder intake of livestock grazing semi-arid subSaharan Africa rangelands. Livestock Science, 216: 16-23. DOI: 10.1016/j.livsci.2018.07.002.

Dardel C, Kergoat L, Hiernaux P, Mougin E, Grippa M, Tucker CJ. 2014. Re-greening Sahel. 30 years of remote sensing data and field observations (Mali, Niger). Remote Sensing of Environment, (140): 350-364.

DOI: 10.1016/j.rse.2013.09.011.

Delon C, Mougin E, Serça D, Grippa M, Hiernaux P, Diawara M, Galy-Lacaux C, Kergoat L. 2015. Modelling the effect of soil moisture and organic matter degradation on biogenic NO emissions from soils in Sahel rangeland (Mali). Biogeosciences, 12. DOI: 10.5194/bg-123253-2015.

Diawara MO, Hiernaux P, Mougin E, Grippa M, Delon C, Diakité HS. 2018. Effets de la pâture sur la dynamique de la végétation herbacée au Sahel (Gourma, 
Mali) : une approche par modélisation. Cahiers Agricultures., 27 : 15010. DOI : 10.1051/cagri/2018002.

Diawara MO. 2015. Impact de la Variabilité Climatique au Nord Sahel (Gourma, Mali) sur la Dynamique des Ressources Pastorales, Conséquences sur les Productions Animales. Ph.D. Thesis, Université Toulouse 3, Toulouse, France, $176 \mathrm{p}$.

http://www.theses.fr/2015TOU30029.

FAO. 2007. Les ruralités en mouvement en Afrique de l'Ouest. Conférence internationale sur la réforme agraire et le développement rural, du 07 au 10 mars, Porto Alegre au Brésil. 73p.

Fernandez-Rivera S, Hiernaux P, Williams TO, Turner MD, Schlecht E, Salla A, Ayantunde AA, Sangaré M. 2005. Nutritional constraints to grazing ruminants in the millet-cowpea-livestock framing systems of the Sahel. Coping with feed scarcity in smallholder livestock systems in developing countries. ILRI, Nairobi, 157-82.

Frappart F, Hiernaux P, Guichard F, Mougin E, Kergoat L, Arjounin M, Lavenu F, Koité M, Paturel J-E, Lebel T. 2009. Rainfall regime over the Sahelian climate gradient in the Gourma, Mali. Journal of Hydrology, 375: 128-142. DOI: 10.1016/j.jhydrol.2009.03.007.

Galle S, Grippa M, Peugeot C, Moussa IB, Cappelaere B, Demarty J, Mougin E, Panthou G, Adjomayi P, Agbossou EK, Ba A, Boucher M, Cohard J-M, Descloitres M, Descroix L, Diawara M, Dossou M, Favreau G, Gangneron F, Gosset $M$, Hector B, Hiernaux $P$, Issoufou B-A, Kergoat L, Lawin E, Lebel T, Legchenko A, Abdou MM, MalamIssa $\mathrm{O}$, Mamadou $\mathrm{O}$, Nazoumou $\mathrm{Y}$, Pellarin T, Quantin G, Sambou B, Seghieri J, Séguis L, Vandervaere J-P, Vischel T, Vouillamoz J-M, Zannou A, Afouda S, Alhassane A, Arjounin M, Barral H, Biron R, Cazenave F, Chaffard V, Chazarin J-P, Guyard H, Koné A, Mainassara I, Mamane A, Oi M, Ouani T,
Soumaguel N, Wubda M, Ago EE, Alle IC, Allies A, Arpin-Pont F, Awessou B, Cassé C, Charvet G, Dardel C, Depeyre A, Diallo FB, Do T, Fatras C, Frappart F, Gal L, Gascon T, Gibon F, Guiro I, Ingatan A, Kempf J, Kotchoni DOV, Lawson FMA, Leauthaud C, Louvet S, Mason E, Nguyen CC, Perrimond B, Pierre C, Richard A, Robert E, RománCascón C, Velluet C, Wilcox C. 2018. AMMA-CATCH, a Critical Zone Observatory in West Africa Monitoring a Region in Transition. Vadose Zone Journal 17: $0 . \quad$ DOI: 10.2136/vzj2018.03.006.

Gilles JL, Jamtgaard K. 1981. Overgrazing in pastoral areas. Sociologia Ruralis, 21: 129-141. DOI: 10.1111/j.1467-9523. 1981.tb01084. x.

Hiernaux P, Mougin E, Diarra L, Soumaguel N, Lavenu F, Tracol Y, Diawara M. 2009. Sahelian Rangeland Response to Changes in Rainfall over Two Decades in the Gourma Region, Mali. Journal of Hydrology, 375: 114-27. DOI: 10.1016/j.jhydrol.2008.11.005.

Hiernaux P, Mougin E, Diawara M, Soumaguel N, Diarra L. 2013. How much does grazing contribute to herbaceous decay during the dry season in Sahel rangelands? Elevage Climat et Société, ECliS 3.4, Géosciences Environnement Toulouse, GET, Toulouse, France, 22p.

Ickowicz A, Ancey V, Corniaux C, Duteurtre G, Poccard-Chappuis R, Touré I, Vall E, Wane A. 2012. Crop-livestock Production Systems in the Sahelincreasing Resilience for Adaptation to Climate Change and Preserving Food Security. Building Resilience for Adaptation to Climate Change in the Agriculture Sector, 23: 261.

Jacques DC, Kergoat L, Hiernaux P, Mougin E, Defourny P. 2014. Monitoring dry vegetation masses in semi-arid areas with MODIS SWIR bands. Remote Sensing of Environment, 153: 40-49. DOI: 10.1016/j.rse.2014.07.027. 
Kergoat L, Hiernaux P, Dardel C, Pierre C, Guichard F, Kalilou A. 2015. Dry-season vegetation mass and cover fraction from SWIR1.6 and SWIR2.1 band ratio: ground-radiometer and MODIS data in the Sahel. International Journal of Applied Earth Observation and Geoinformation, 39: 56-64. DOI: 10.1016/j.jag.2015.02.011.

Krätli S, Kaufmann B, Roba H, Hiernaux P, Li W, Easdale M, Hülsebusch C. 2015. A House Full of Trap Doors. http://pubs.iied.org/pdfs/10112IIED.pdf.

Lhoste P. 2007. Sociétés pastorales et désertification au Sahel. Bois et Forêts des Tropiques, 3: 49-59.

McLeod SR. 1997. Is the Concept of Carrying Capacity Useful in Variable Environments? Oikos, 79(3) : 529-542. DOI: $10.2307 / 3546897$.

Mougin E, Hiernaux P, Kergoat L, Grippa M, de Rosany P, Timouk F, Le Dantec V. 2009. The AMMA-CATCH Gourma Observatory site in Mali: relating climatic variations to changes in vegetation, surface hydrology, fluxes and natural resources. Journal of Hydrology, 375: 14-33. DOI: 10.1016/j.jhydrol.2009.06.045.

Nicholson SE. 2013. The West African Sahel: A Review of Recent Studies on the Rainfall Regime and Its Interannual Variability. ISRN Meteorology, 1-32. DOI: $10.1155 / 2013 / 453521$.

Sanon O, Ouattara F, Sawadogo M. 2015. Seasonal dynamic of herbaceous fodder production in the Sahelian pastures used by domestic ruminants. Journal of Agriculture and Environment for International Development (JAEID), 109: 123-138. DOI: 10.12895/jaeid.20151.317.
Schlecht E, Hiernaux P, Kadaouré I, Hülsebusch C, Mahler F. 2006. A spatio-temporal analysis of forage availability and grazing and excretion behaviour of herded and free grazing cattle, sheep and goats in Western Niger. Agriculture, Ecosystems \& Environment, 113: 226-42. DOI: 10.1016/j.agee.2005.09.008.

Toulmin C. 1985. Livestock losses and postdrought rehabilitation in sub-Saharan Africa. LPU working paper $\mathrm{N}^{\circ}$. International Livestock Centre for Africa, Addis Ababa, Ethiopia.

Valenza J, Diallo AK. 1972. Étude des Pâturages du Nord Sénégal. IEMVT: Paris; 311p.

Weber KT, Horst S. 2011. Desertification and livestock grazing: The roles of sedentarization, mobility and rest. Pastoralism: Research, Policy and Practice 1, 19.

Wilson RT. 2003. Livestock Production and farm animal genetic resources in the Usangu Wetland of the Southern Highlands of Tanzania. Livestock Research for Rural Development, 15 (1). http://www.lrrd.org/lrrd15/1/wils151.ht $\mathrm{m}$

Zampaligré N, Kagambega WF, Sanou L, Sawadogo L. 2019. Impact of Grazing Intensity on Floristic Diversity and Woody Structure in Grazing Area Near Kaboré Tambi National Park (Burkina Faso). Journal of Agriculture and Environmental Sciences, 8(2). DOI: 10.15640/jaes.v8n2a13. 